\title{
Hedges and Boosters in Indonesian Scientific Articles
}

\author{
Hanung Triyoko, ${ }^{1 *}$ I Dewa Putu Wijana, ${ }^{2}$ I Praptomo Baryadi ${ }^{3}$ \\ ${ }^{1} J u r u s a n$ Tadris Bahasa Inggris, Fakultas Tarbiyah dan IImu Keguruan IAIN Salatiga, Indonesia, \\ 2Jurusan Sastra Indonesia, Fakultas IImu Budaya, Universitas Gadjah Mada, Yogyakarta, \\ Indonesia ${ }^{3}$ Jurusan Sastra Indonesia, Fakultas Sastra, Universitas Sanata Dharma, Indonesia \\ *) Corresponding Author \\ Email: hanungina@iainsalatiga.ac.id \\ DOI: $10.18326 /$ rgt.v14i1.65-82
}

\section{Submission Track:}

Received: 26-01-2021

Final Revision: 09-03-2021

Available Online: 01-06-2021

Copyright (C) 2021 Authors

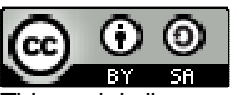

This work is licensed under a Creative Commons Attribution-ShareAlike 4.0 International License.

\begin{abstract}
Hedging and boosting or 'pembentengan' (Indonesian) is the act of scientific writers in maintaining the smooth scientific communication. This paper answers two problem formulations, i.e., what are the linguistic manifestations of hedges and boosters in Indonesian scientific articles, and how their meaning reveals the writer's level of confidence in the information conveyed. This study aims to enrich the description of scientific writing practices in Indonesia to support the development of scientific writing skills in general. This research uses descriptive qualitative methods. This research data is in the form of sentences containing hedges and boosters from various scientific journals published in Indonesia through the notetaking technique. The main theory to analyze the data is the theory on hedges and boosters. The data were analyzed semantically, syntactically, and pragmatically. The results show that hedges and boosters in the form of adverbs are the most commonly used in Indonesian Scientific writing. The meaning of hedges and boosters cannot always be determined by their lexical meaning because each hedge and booster has to be seen in its use in the sentence. The Indonesian scientific community has its own agreement in the social interaction of scientific articles.
\end{abstract}

Keywords: scientific writing; hedges and boosters; confidence; doubt; function; interaction 


\section{INTRODUCTION}

Hedges and boosters are part of the metadiscourse by which a writer makes the text easier for the audience to understand. Metadiscourse is defined by Crismore et al. as language material, in speech or writing, which does not add to the content of sentence information but is used to help listeners or readers organize, interpret, and evaluate the information contained in the text (Chrismore et al, 1993). This serves the interactive characteristic of metadiscourse (Thompson, 2001).

Hedges and boosters can be considered as the interactive elements of a text that functions to bridge the content of information in the text and the writer's interpretation of that information. (Salager-Meyer, 1997). A hedge when viewed from a semantic perspective, can be classified as the second modality of meaning as proposed by Alwi (1992), namely the meaning of attitudes related to propositional truth, which is called the epistemic attitude gradation of sureness or uncertainty. However, the function of hedging or boosting is not always manifested linguistically as a modality.

Hedge or booster is a linguistic marker that is used to carry out functions related to social actions that accompany the composition of texts that allow writer and reader interaction called as the interpersonal or interactional function of metadiscourse (Hyland, 1998), (Hyland \& Polly, 2004). This is the main theory by which the data is analyzed so basically the researcher starts with reading all articles publication as the source of data of this research and then find those sentences when the writers interact with the readers using linguistic elements that do not add to the content of sentence information but are functional to express the interpretation or attitude of the writer of these sentences to the information conveyed. In examples (1) hedge is used to reveal doubts or delay the writer's commitment to the correctness of the sentence information.

Hedges and boosters are found both in Indonesian scientific essays in the natural science and social science groups. Hedges generally function to lower the power of asserting the correctness of information conveyed by scientific article writers while the information conveyed remains because the information provider (the writer or the speaker) has the aim of obscuring or 
clarifying the information conveyed (Lakoff, 1973). Information is often interpreted simply as the content of an oral expression or the content of a written statement in language communication. Information has long been proposed by Aristotle and restated by Gaskin (2008) as "the meaning of a declarative sentence, whereas a declarative sentence is a sentence that can be meaningfully stated as true or false, thus information can also be stated as true or false". Gibson (2004) urges that the sentence is the necessity to be a container of information.

Researches on the use of hedges and boosters in scientific articles in crosslanguage studies were carried out by, among others, Sanjaya (2013) and Sanjaya, Sintawati, and Suciani (2015). Sanjaya (2013) proves that overall scientific articles in English are more expressive of transient information than scientific articles in Indonesian by seeing the more frequent use of hedges in scientific articles in English. Sanjaya, et al. (2015) clarify the typology of using hedges in Indonesian scientific articles in terms of the similarities and differences with the use of hedges in English scientific articles. This dissertation research is different from the two studies because this dissertation research is not a cross-language research. This research relies entirely on the findings of data on the embodiment of hedges and boosters in Indonesian scientific articles as a basis for describing hedges and boosters in the Indonesian context. Comparisons or references to writing practices or cultures in other languages are only used when necessary to clarify or emphasize the uniqueness of the Indonesian context of using hedges and boosters in Indonesian scientific articles so that comparison is not a goal but a way of discussion.

Wibowo (2011) examines the use of hedges and boosters in the editorial of Indonesian newspapers. Wibowo concluded that hedges are commonly used by editorial writers as an epistemic modality to disguise or disclose things such as numbers, actors, possibilities, accuracy, and involvement of the readers. In this study, Wibowo did not propose strict criteria for linguistic manifestation in Indonesian or Bahasa which could be categorized as functioning as hedges and boosters because Wibowo limited the discussion of hedges in the context and co-texts of newspapers editorial while this dissertation research discusses formations in the context and co-text of scientific articles and this dissertation uses syntactic, semantic, and pragmatic viewpoints to describe hedges and 
boosters. Besides, the language of journalism is more popular and often lacks of intellectual rigour compared to the language of academia. (Duffy, 2015).

Hardjanto (2017) in his dissertation writing entitled Pembentengan dalam Artikel Penelitian Ilmiah dalam Bahasa Inggris 'Hedges and Boosters in English Scientific Research Articles' describes the ins and outs of hedges and boosters related to its lingual form and function. Hardjanto's dissertation research presents important findings including that the field of science of scientific articles does not seem to affect the frequency or number of uses of the lingual form of hedges and boosters used and that the form of hedge and booster is used as a defensive-protective strategy for the writer to protect three things, namely the proposition, the writer, and the reader. Tofan's dissertation was written in Indonesian, but the object of his research was hedges and boosters in English so that this research for a dissertation with the object of research is the hedges and boosters in Indonesian scientific articles is still very much needed.

There are three reasons for the importance of the description of hedges and boosters in Indonesian scientific articles, namely, first, a description of the matters of hedges and boosters in Indonesian scientific articles has not been carried out or it can be said that it has not been found in the Indonesian literature in the field of discourse analysis or scientific writing as a reference for discussion of hedges and boosters. The discussion on hedges and boosters in this dissertation can be an adequate contribution to the explanation of the various efforts made by scientific writers as the sole holder of communication initiatives in maintaining social interaction with readers in order to smooth the scientific communication in the Indonesian context. Second, knowledge of hedges and boosters in scientific articles in Indonesian is part of the basic needs of developing practical skills in Indonesian scientific writing so that this dissertation can enrich the descriptions of scientific writing practice in Indonesia at the time this dissertation was compiled. Third, the results of research on hedges and boosters in scientific articles in Indonesian or Bahasa will be part of an effort to compile a more comprehensive knowledge of the manifestation of social interaction in scientific articles in the Indonesian context.

This article answers two main questions, first, what are the linguistic manifestations of hedges and boosters in scientific articles in Indonesian and second, how the meaning of the formation reveals the writer's level of 
confidence in the information he conveys, starting from the range of doubt to the range of belief.

\section{RESEARCH METHOD}

This research used a qualitative descriptive method by describing hedges and boosters used in Indonesian scientific articles syntactically, semantically and pragmatically. It is based on three premises that first hedges and boosters are used in a formal style of the scientific articles and therefore hedges and boosters are rigidly governed by the formal syntactical rules of Bahasa Indonesia. Second, the choice of the manifestation of hedges and boosters is based on the closest intended meaning of the writers' expressions of his/her attitudes toward the information conveyed in the sentences. Third, in using hedges and boosters, the writers have some pragmatic reasons other than just expressing their attitudes toward the information. This is different to three premises proposed by Jumanto and Sulistyorini (2019:326) based merely on the pragmatic aspect of utterances.

The research data is in the form of sentences containing the formations of 70 scientific article titles in Indonesian, published in the year between 2000 and 2017 from various fields of science. The data consists of 281 sentences containing 76 different hedges and 120 different boosters. The data were collected in between April 2018 to August 2018.

The research data were collected using the note taking technique (Sudaryanto, 1993) or the 'taking note method' (Muhammad, 2012). The researcher starts with reading all articles publication as the source of data of this research and then find those sentences when the writers interact with the readers using linguistic elements that do not add to the content of sentence information but are functional to express the interpretation or attitude of the writer of these sentences to the information conveyed. The research instrument for this dissertation is in the form of a collection table of sentences from reading scientific articles, and determining hedges and boosters based on the categories of the constituent words, patterns of use in sentences and reasons for their use using the skills and intuition of researchers, as native speakers of Indonesian and as part of the scientific community of Indonesia. The data are considered as accurate firstly by ensuring that they are taken from published Scientific articles 
in Bahasa Indonesia in the forms of pdf file and secondly by ensuring that they consist of the linguistic elements serving as hedges or boosters and the linguistic elements containing the information shared by the writer.

For the data analysis method, the researcher classifies the linguistic units that contain the hedges and boosters based on the similarity of the linguistic markers, either in the form of words or phrases or even clauses, disclosing the hedges and boosters. Through this grouping, the researcher then describes semantically and syntactically the linguistic unit pattern that contains hedges and boosters. In the end, it is pragmatically determined that the function of the language unit containing the formation is in accordance with the similarity of the linguistic unit pattern.

\section{DISCUSSION}

\section{Categories of Hedges and Boosters in Indonesian Scientific Articles}

Based on the word categories proposed by Kridalaksana (1986) and Ramlan 1991, the hedges and boosters found in Indonesian scientific articles can be grouped into (i) hedges and boosters in the verb category, (ii) hedges and boosters in the adverb category, (iii) hedges and boosters in the adjective category, (iv) hedges and boosters categorized as modality, and (vi) the phatic category of hedges and bosters as each of the examples is shown in the following sentences:

(1) Hasil yang diperoleh ini mengindikasikan bahwa sebagian besar istri dapat melakukan proses penyesuaian diri yang baik dengan keluarga suami. (PSI 2012, Nova 62)

"The results obtained indicate that most wives can make a good adjustment process with their husband's family"

(2) Dari hasil studi itu diperkirakan kedalaman batuan dasar di wilayah Jakarta pada $200 \mathrm{~m}$ hingga $480 \mathrm{~m}$. (Jurnal Teknik Sipil 2017, Delfebriyadi dkk, 161)

"From the results of the study it is estimated that the depth of the bedrock in the Jakarta area is $200 \mathrm{~m}$ to $480 \mathrm{~m}$." 
Sentences (1) and (2) are examples of hedges and boosters that are manifested by word categorized as verbs. When viewed from the relationship between verbs and nouns in a sentence, the verbs that are used as hedges and boosters can be classified into active verbs such as menegaskan 'affirming', mencoba 'trying', mengindikasikan 'indicating', memperlihatkan 'showing', menunjukkan 'pointing', membuktikan 'proving', menggambarkan 'describing' and some others are passive verbs such as dirasa 'to be felt', diduga 'to be suspected', diperkirakan 'to be estimated', dipungkiri 'to be denied', and disinyalir' to be presumed'

The following sentences number (3) show a hedge that is manifested by adverb categorized words.

(3) Budaya Jawa menempatkan perempuan seolah-olah menjadi nomor dua. (Filsafat 2016 Iva Ariani 287)

'Javanese culture places women as if number two'

Six groups of adverbs are found used as hedges and boosters through this research, namely the first, adverb that accompanies the verb. The second, adverbs accompany the adjective. The third, adverbs accompany the noun. The fourth, adverbs accompany other adverbs. The fifth, adverbs accompany the clause. The sixth, adverbs accompany the sentence and the seventh, adverbs whose manifestation is marked by the use of pun as the phatic word, such as sekalipun 'eventhough', manapun 'whereever/whatever', bagaimanapun 'however'.

The example sentences of using a booster in scientific articles number (4) below is manifested by word categorized as adjective.

(4) Pengemis merupakan suatu gejala sosial yang sampai saat ini belum menemukan solusi yang nyata untuk menyelesaikannya. (SosPol 2012 Putri 10)

"Begging is a social phenomenon which until now has not found a real solution to solve it."

While the sentence number (5) below is one of the examples of hedge that is manifested by noun. 
(5) Fenomena yang terjadi akhir-akhir ini sangat lah memprihatinkan, karena kecenderungan merosotnya moral bangsa hampir terasa di semua strata kehidupan. (Psi 2012 Aprius 86)

"The phenomenon that has occurred recently is very concerning, because the tendency to decline in national morals is almost felt in all strata of life."

While a booster that is realized by modality can be found in the example sentence number (6) below:

(6) Suatu ajaran atau pendapat harus dapat diperiksa atau diuji kebenarannya dengan pengalaman langsung dari penglihatan dan pendengaran orang banyak. (Filsafat 2016 Budisutrisna 9)

"A teaching or opinion must be checked or verified by direct experience from the sight and hearing of the crowd."

Finally, there are very few examples of hedges or boosters manifested in phatic category like seen in example sentence number (7) below:

(7) Sebetulnya P2KP bukanlah satu-satunya program penanggulangan kemiskinan yang dilakukan di perkotaan. (Politika 2010 Ahmad 76)

"In fact, P2KP is not the only poverty reduction program implemented in urban areas."

This evidence of the use of boosters in phatic category is in accordance to Kridalaksana's statement that "Different forms are always seen as motivated by different meanings" (Kridalaksana, 2002: 75). The use of the phatic word 'lah' in bukanlah satu-satunya 'not the only' make the sentence expresses higher confidence of the writer toward the information shared in the sentence though the meaning of the combination of words is similar to bukan satu-satunya 'not the only'. This linguistic phenomenon also serves as evidence that every little different in the use of linguistic elements, such as the use of the phatic word 'lah' is there for a reason,or is there as a product of the mind as suggested by Baryadi (2013:49) that meaning formation process involves thoughts, symbols (language), and references.

\section{Meaning of Boosters and Hedges and Various Sentence Patterns with Hedges and Boosters}


In the following, we will present a few sample sentences from the entire example sentences with various kind of boosters that express the writer's confidences from strong to weak.

\section{Boosters Revealing High Confidence}

A booster in sentence (8) reveals the writer's confidence in the sentence information at its high ranges.

(8) Hal ini membuktikan bahwa dinding bata penuh dalam struktur rangka berkontribusi dalam menahan beban lateral seperti beban gempa bumi. (Jurnal Teknik Sipil 2017 Maidiawati dkk. 146)

"This proves that the full brick wall in the frame structure contributes to withstand lateral loads such as earthquake loads."

The writer's choice of the use of a booster in the category of verb formation in active sentences as in the example sentence number (8) is the writer's selection of a booster that reveals the meaning of high confidence ranges. Selection of active sentences with the use of the word membuktikan 'proves' that has more intensity or effort compared to other words that share elements of meaning similar to that of membuktikan such as menggambarkan 'describing', menunjukkan 'pointing', memperlihatkan 'showing' is the writer's way of selecting boosters that reveal a range of high confidence meanings. The use of negation as a booster also adds to the height of the writer's conviction. The use of tidak cukup 'not sufficient' as a substitute for the meaning of the word kurang 'lacking' is the writer's way of enhancing his belief.

Other sentences with boosters that express the writer's belief in sentence information at a high level are sentences that use adverbs whose denotative meaning contains elements of the meaning of 'absolutes' such as sama sekali 'completely', mutlak 'absolutely', otomatis 'automatically', bagaimanapun (juga) 'however', manapun 'wherever', sekalipun 'eventhough', tentu saja 'of course', pasti 'certain', jelas 'clear". Also adverbs whose denotative meanings contain elements of the meaning 'mostly', 'always', or 'very' like the following adverbs kebanyakan 'mostly', seringkali 'often', kerap 'often', senantiasa 'always', hampir-hampir 'almost', biasanya 'usually', secara konsisten 'consistently', sangat 'very', terlalu 'too + Adj". Often also in the form of adverbs that contain elements of the meaning 'real' such as sebenarnya 'trully', sungguh 'really', 
sesungguhnya 'really', sebetulnya 'actually', ternyata 'in fact', and nyata 'real'. This group includes adverbs that contain elements of the meaning of 'affirmation' also such as hanya 'only', terutama 'mainly', bahkan 'even', sekali lagi 'once again', setiap 'any', apalagi 'moreover', pada dasarnya 'basically', tegasnya 'strictly', belum pernah 'have never ...'.

What is interesting is that the booster belum pernah 'have never ...'. though its meaning may conflict with the word pernah 'ever', or tidak pernah 'never' but these three adverbs have the same function, namely increasing the writer's confidence in sentence information. The readers accept the three as an emphasis on sentence predicates and add to the writer's confidence in the propositions of those sentences. There is also a booster in the adverbial formation bahkan 'even' located at the beginning of a sentence which is generally avoided in in a formal language style to add confidence to the sentence proposition even though the word bahkan 'even', semantically does not express beliefs and doubts.

(9) Bahkan anggaran daerah sering pula tertunda karena keterlambatan DPRD untuk menyetujuinya (Politika 2010 Fitriyah, 59)

"Even, local budgets are often delayed due to the DPRD's delay in approving them."

\section{Boosters Revealing Moderate Confidence}

Among the examples of sentences with boosters that express belief in a moderate range are boosters which are manifested by verbs which denotatively contain the element of the meaning 'to show' such as the verb menggambarkan ' to describe', menunjukkan ' to point', memperlihatkan 'to show', as seen in the following example sentence number (10).

(10) Trading activity yang tinggi menggambarkan usaha Manajer Investasi dalam mewujudkan return yang maksimal dengan melakukan perdagangan pada saat yang tepat (Ijtihad 2016 Setia, 229)

"High trading activity describes the investment manager's efforts in realizing maximum returns by trading at the right time." 
Through a series of high and low beliefs expressed by the boosters as illustrated with figure 1 below, it can be conveyed that mengindikasikan 'to indicate', memperlihatkan 'to show', menunjukkan 'to point', menggambarkan 'to describe', membuktikan 'to prove' have different degrees of confidence. The researcher found no other way to determine the high and low levels of belief through verbs that share certain elements of the same meaning such as menggambarkan 'to describe', menunjukkan 'to point', memperlihatkan 'to show' except by considering the elements of meaning of those words disclosing the boosters.

\section{Figure 1}

Keraguan (doubt) Keyakinan (confidence)

mengindikasikan, (...daerah transisi ...) mengambarkan,

menunjukkan, memperlihatkan, membuktikan

'to indicate', (...transitional area, ...) 'to describe',

'to point', 'to show', 'to prove'

Figure 1 also shows that the range of beliefs and doubts is in one line, but it does not mean that the highest belief can be called the lowest doubt or vice versa, the highest doubt is the lowest belief because the movement to the right in the sequence or towards the belief further clears the doubt. and movement to the left in the sequence or towards doubt further eradicates belief so that there is a transition area for the cessation of doubt towards belief and vice versa.

The use of certain adverb groups which are used to avoid stating a certain number or reduce the absolute number or frequency and to reduce the intensity of seriousness such as hampir 'almost', hampir-hampir 'almost all', banyak 'a lot', cukup 'enough', betapa 'how- ...' , sampai-sampai 'to the point that ...', setidaknya 'at least', seharusnya 'should be'also express the writer's belief in the sentence information in the medium range of confidence.

\section{Boosters Revealing Low Confidence}

An example of a sentence with boosters that expresses the writer's belief in sentence information that is in the low confidence range is represented by 
sentences that use the modality function, namely, rupanya 'apparently', bisa 'can'. They can also use double boosters and hedges such as rupanya tidak sepenuhnya 'that are apparently incomplete', bisa menduga dengan sangat kuat 'can predict very strongly', and dapat ditunjukkan 'can be demonstrated,' which is a way to reduce confidence.

\section{Hedges Revealing High Doubt}

Sentences with high-doubt revealing hedges use double hedges such as tampaknya bisa diasumsikan 'it seems to be assumed ...', relatif cukup 'relatively sufficient', and mungkin dianggap 'might be assumed as ...'. Many hedges are also found to be manifested in passive sentences with verbs beginning with (di-) so that the hedges such as dirasa 'as it is felt', diduga 'suspected', disinyalir 'allegedly', diperkirakan 'estimated', dianggap 'considered' are examples of hedges to express the writer's doubts over the information in high ranges.

Hedges like dirasa 'as it's felt', diduga 'suspected', disinyalir 'allegedly', diperkirakan 'predicted', dianggap 'considered' also indicate that there's a rating of doubtful power with the highest sequence of doubt expressed by the hedge dirasa 'as it's felt' Hedges with the lowest range of doubt or at the very end of the line going to the direction of belief, although it's still in the range of doubt, is the hedge dianggap 'considered'. Thus we get the order of hedges as follow dirasa 'as it's felt', diduga 'suspected', disinyalir 'allegedly', diperkirakan 'predicted', dianggap 'considered' as illustrated with figure 2 below.

\section{Figure 2}
Keraguan (doubt)
Keyakinan (belief)

dirasa, diduga, disinyalir, diperkirakan, dianggap,
(daerah transisi)
'as felt', 'suspected', 'allegedly', 'predicted', 'considered'
(transitional area)

\section{Hedges Revealing Moderate Doubt}

Hedges manifested through the following adverbs are used by the writer to express the meaning of a moderate range of doubts, namely cenderung 'tend to', cukup 'sufficient', kadang-kadang 'sometimes', terkadang 'sometimes', 
seolah (-olah) 'as if', tampaknya 'likely', agaknya 'seem', barangkali 'perhaps', rupanya 'apparently', sementara 'temporary', and relatif 'relative". Moderate doubt revealing hedge is also manifested by adverbs that accompany verbs whose meaning is to express doubt or uncertainty as kadang-kadang 'sometimes', terkadang 'sometimes', tampaknya 'as if', seolah 'as it were', seolaholah 'as if', tampaknya 'likely' and agaknya 'presumably'. Also, adverbials whose meaning does express temporariness like sementara 'temporrily'. It can also be manifested with a modality as an introduction to sentences, namely barangkali 'perhaps' and tampaknya 'apparently'.

\section{Hedges Revealing Low Doubt}

Sentences with a hedge in the form of noun kecenderungan 'tendency' and a noun phrase besar kemungkinan 'most likely' are to express low doubt. Contrary to the findings on adjective category formation which entirely reveals the meaning of the writer's range of confidence in sentence information, the hedges manifested in noun found in scientific articles in Indonesian as a whole reveals the meaning of the writer's range of doubts on sentence propositions.

\section{Various Sentence Patterns with Hedges and Boosters in Indonesian Scientific Articles}

There are various linguistic units in Indonesian scientific writing that contain hedges and boosters. Hedges and boosters can be found in clauses, simple sentences, compound sentences, complex sentences, sentences with negation, sentences with modalities, introductory sentences, etc.

Analyzing the data inductively as suggested by Djajasudarma (1993:12), Indonesian scientific writers have a choice of the following linguistic patterns: 1) Sentences with predicates in the form of verbs filled in by lexicals whose meaning represents the level of the writer's confidence in the information, either doubt or belief. 2) Sentences with adverbs filled with modalities or groups of adverbial words which significantly reduce or increase the writer's confidence in the information presented. 3) Sentences with the use of lexical groups categorized as adjectives whose meaning reduces or adds to the writer's confidence in the information conveyed. 4) Sentences with the use of nouns that mean doubt or belief or are in the meaning of a range of doubts or beliefs. The data of this study indicate that nouns are only used as hedges to reveal 
doubts. 5) It is the sentence with the use of the phatic word category that emphasizes the sentence predicate and at the same time adds the writer's confidence to the sentence proposition. 6) Sentences with the linguistic manifestation of double or multiple hedges and boosters. 7) Sentences with negation. 8) Conditional Sentences.

Those 8 patterns of sentences containing hedges and/or boosters make the meaning of the hedges or the boosters themselves cannot be determined from the meaning of the lexicals disclosing the hedges or the boosters, because each hedge and booster has to be seen in its use in the sentence This is in line to what Subroto says that "The meaning of the lingual unit is the meaning that the lingual unit has in relation to other lingual units in a speech" (Subroto, 2011: 23).

\section{The range of Beliefs or Doubts of Scientific Writers is Conveyed through the Choice of Sentence Patterns with Hedges or Boosters}

The meaning of sentences with one hedge or booster depend on the lexical or lexical combination meaning that the writer chooses. Sentences with hedges or boosters in Indonesian scientific articles can consist of more than one hedge or booster in one sentence, like sentence number (11).

(11) Sejarah politik kita menunjukkan bahwa perubahan-perubahan politik besar di masa lalu seakan menegaskan bahwa ketiga hal tersebut tidak dapat dicapai sekaligus atau berjalan seiring. (Politika 2010 Purwoko, 60)

"Our political history shows that the major political changes of the past seem to confirm that these three things cannot be achieved at once or go hand in hand."

In a sentence with double hedges and/or boosters such as sentence (11), the atmosphere that is captured by the reader in the form of belief or doubt is determined by the first hedge or booster in the sentence or by the dominance of the range of beliefs or doubts that are manifested through the lexical selection of the hedges and boosters. In sentence number (11) of the two hedges and boosters contained, the first hedge shows the meaning of the range of doubt, because the power of confidence contains in the meaning of the lexical menunjukkan 'pointing' is smaller than the power of other lexical which is 
synonymous with that lexical such as memperlihatkan 'showing', and membuktikan 'proving'. The lexical which means doubt used as a hedge in sentence number (11) menunjukkan 'showing' and seakan 'seem' are more dominant to create an atmosphere of doubt compared to another lexical of booster in sentence (11), namely menegaskan 'affirming' so that the atmosphere generated by the sentence is the writer's doubt. Thus, the reader interprets sentence number (11) as a sentence that has the atmosphere of the writer's doubts about the sentence proposition.

\section{CONCLUSION}

As an answer to the the first research question, it is concluded that adverb is the most commonly used either as hedges or boosters in Indonesian scientific articles. Meanwhile, the least used hedges or boosters disclosers are the phatic words. For the second question about the meaning and pattern of hedges and boosters linguistic units, it is concluded that the meaning of hedges and boosters cannot always rely on the lexical meaning that fills the language units of the hedges or boosters because each of them must be seen in their use in the sentence. Sentences with one form of hedge or booster, its meaning depend on the lexical meaning or lexical combination that the writer chooses. In a sentence with double hedges and/or boosters the striking atmosphere that is captured by the reader is determined by the first hedge or booster in the sentence or by the dominance of the range of beliefs or doubts that are manifested through the lexical selection of the hedges or boosters.

The researcher suggests that for the future research on hedges and boosters in Indonesian scientific articles, the focus can be shifted on the how and why hedges and boosters are used, to add to this research explanation on what hedges and boosters are used.[rgt]

\section{REFERENCES}

Alwi, H. (1992). Modalitas dalam Bahasa Indonesia. Kanisius.

Baryadi, I. P. (2002). Idiom yang berunsur kata kerja dalam Bahasa Indonesia. Sintesis, 7 (1), 46-62. 
Crismore, A., Markkanen, R. and Steffensen, M. (1993) 'Metadiscourse in persuasive writing: a study of texts written by American and Finnish university students'. Written Communication, 10(1), 39-71.

Djajasudarma, F. T. (1993). Metode linguistik ancangan metode penelitian dan kajian. Eresco.

Duffy, A. (2015). Journalism and academic writing sibling rivalry or kissing cousins?" Asia Pacific Media Educator, 25 (1). https://doi.org/10.1177/ $1326365 X 15575562$.

Gaskin, R. (2008). The unity of the proposition. Oxford University Press.

Gibson, M. I. (2004). From naming to saying: The unity of the proposition. Blackwell Publishing Ltd.

Hardjanto, T. D. (2007). Pembentengan dalam artikel ilmiah dalam Bahasa Inggris. Universitas Gadjah Mada, Yogyakarta.

Hyland, K. (1994). Hedging in scientific articles and EAP textbooks. English for Specific Purposes, 13(3), 239-256. https://doi.org/10.1016/08894906(94)90004-3

Hyland, K. (1998). Boosting, hedging an the negotiation of academic knowledge. Text - Interdisciplinary Journal for the Study of Discourse 18(3), pp 349-382. https://doi.org/10.1515/text.1.1998.18.3.349

Hyland, K. \& Tse, P. (2004). Metadiscourse in academic writing; A reappraisal. Applied Linguistics, 25(2), 156-177. https://doi.org/10.1093/applin/25.2. 156

Jumanto and Sulistiyorini, H. (2019). The pragmatics of swearing; How It contextually counts. 3rd English Language and Literature International Conference (ELLiC) Proceedings - (ELLiC Proceedings Vol. 3, 2019)

Kridalaksana, H. (1986). Kelas kata dalam Bahasa Indonesia. Gramedia Pustaka Utama

Kridalaksana, H. (2002). Struktur, kategori, dan fungsi dalam teori sintaksis. Universitas Katolik Indonesia Atma Jaya.

Lakoff, G. (1973). Hedges: A study in meaning criteria and the logic of fuzzy concepts. Journal of Philosophical Logic, 2, 458-508.

Muhammad. (2012). Metode dan teknik analisis data linguistik. Liebe Book Press.

Pateda, M. (2001). Semantik leksikal. Rineka Cipta.

Ramlan, M. (1991). Sintaksis. CV. Karyono. 
Salager-Meyer, F. (1997). I think that perhaps you should; A Study of Hedges in Written Scientific Discourse. In Miller, T. (Ed.). (1997). Functional Approaches to Written Text; Classroom Applications. United States Information Agency.

Sanjaya, I. N. S. (2013). Hedging and Boosting in English and Indonesian Research Articles. The Pennsylvania State University

Sanjaya, I. N. S., Sitawati, A. A. R., and Suciani, N. K. (2015). Comparing hedges used by English and Indonesian scholars in published research articles: A corpusbased study. TEFLIN Journal, 26(2), 209-227. http://doi.org/10.15639/ teflinjournal.v26i2/209-227

Sudaryanto, S. (1993). Metode dan aneka teknik analisis bahasa (Pengantar penelitian wahana kebudayaan secara linguistis). Duta Wacana University Press.

Subroto, E. (2011). Pengantar studi semantik dan pragmatik. Cakrawala Media.

Thompson, G. (2001.) Interaction in Academic Writing: Learning to Argue with the Reader. Applied Linguistics, 22(1), 58-78. https://doi.org/10.1093/ applin/22.1.58

Wibowo, A.H. (2011). penggunaan hedge' dalam editorial surat kabar: Analisis bentuk dan makna serta interpretasi perspektif kewartawanan. University Utara Malaysia. 
The page has been intentionally left blank. 